\title{
Chapter 8 \\ Translocal Activities of Local Governments and Migrant Organizations
}

\author{
Edith van Ewijk and Gery Nijenhuis
}

\section{Introduction}

Linkages between migrant source and destination countries can take many forms, ranging from informal remittances sent by individual migrants to relatives "back home" to diaspora engagement policies of sending countries. These relationships are often locally specific (Nell 2007). After all, migrants send remittances not to some random village, but to their villages of origin. Some authors refer to linkages at the local level as "translocal":

[W]hile people are indeed more and more connected to others in different localities, including distant ones, the essence of this integration lies in linking 'the local' to 'the local' elsewhere and only partly in integration at the level of nation states (Zoomers and Van Westen 2011, 377).

This chapter examines the translocal relationships that link local governments and migrant organizations in a country of origin with those in a country of destination. We define translocal linkages as local-to-local connections across national boundaries created through local governments (villages, cities, or regions) and migrant organizations. As such, we take a meso-level perspective. At the meso level, actors play a specific role. They are often involved in more or less institutionalized linkages through which individual migrants and other actors pool resources, share experiences, exchange knowledge, and engage with one another. These linkages are usually rather structural and stable, and relatively flexible, and they are able to respond to local needs (Robertson 1994; Pries 2001; Nell 2007; Penninx 2005; Bockhove 2012).

E. van Ewijk $(\square)$

Kaleidos Research, Barcelona, Spain

e-mail: evanewijk@kaleidosresearch.nl

G. Nijenhuis

Utrecht University, Utrecht, The Netherlands 
The bulk of the literature on transnational practices focuses on either the macro level, such as the policies of sending countries (see Østergaard-Nielsen in this volume; Østergaard-Nielsen 2011), or the micro level, for example, the remittance behaviour of individual migrants and the impact of remittances on countries of origin (see Mügge in this volume). So far, few researchers have looked specifically at the meso level. Those who have done so have mainly focused on the linkages of US-based migrant organizations (e.g., Mexican hometown associations) with Latin America (Fauser 2007; Østergaard-Nielsen 2011).

This chapter reviews the literature on the linkages of, respectively, local governments and migrant organizations between countries of origin and countries of destination. Three questions are central: (i) What are the main characteristics of these relationships and what kinds of activities can be observed? (ii) What drives local governments and migrant organizations to implement these activities? (iii) How can we assess these activities?

In addressing these questions, this chapter touches upon two overarching debates that are central in this publication. The first is the increasing prominence of the migration and development framework (see King and Collyer in this volume). Related to this, several European countries have established co-development programmes aimed at linking immigrants and their organizations to development processes in the region of origin, often with the aim of stimulating integration processes in destination countries as well. The second debate is related to this and centres on whether translocal linkages between migrant source and destination countries and integration in destination countries reinforce each other or are a zero-sum proposition (see also Mügge in this volume).

\section{Local Governments as Actors in Transnational Exchange}

Numerous governments in European countries of destination support migrant initiatives or maintain linkages with municipalities in origin countries. These linkages are often associated with policies for strengthening social cohesion and integration in their own societies. The connection between international cooperation policies and policies on citizenship and integration at the local level is a relatively new phenomenon in Europe. Reflecting this, there is little scientific research on international cooperation between cities in origin and destination countries. Although several studies mention the existence of these bonds and the main reasons for establishing them, empirical evidence on these partnerships is scarce. There are also few policy-oriented studies. ${ }^{1}$

\footnotetext{
${ }^{1}$ One policy-oriented study describes 16 cases of European-based city-to-city partnerships including bonds between Pajkot (India) and Leicester (UK), Nanino (Colombia) and Catalonia (Spain), and Ouagadougou (Burkina Faso) and Lyon (France). According to the description, the focuses of these partnerships were on strengthening development and capacity building in the Global South only, and no reference was made to involvement of migrants or their organizations. Only in the Leicester case was reference made to engagement of the community in Leicester and new skills in cross-cultural work (Smith n.d.).
} 
Before discussing the role of local governments, it is important to note that government structures vary widely within Europe, in terms of their extent of decentralization and the mandates of local governments. These differences have a strong effect in the shaping of immigration and immigrant policies, as well as on international cooperation policies (Juzwiak et al. 2014). Beyond the extent of decentralization, the kind of local government entities involved in international cooperation varies widely. Whereas in Spain and Italy regions fulfil an important role, in the Netherlands international exchange is usually executed by municipalities, with regions playing only a minor role. Two general observations can be made: (i) not all European destination countries have experienced engagement of local governments in international cooperation with origin countries, (ii) in those countries where they do engage, only a limited number of local governments are involved.

\section{Characterizing the Transnational Activities of Local Governments}

Local governments in migrant destination countries are said to have certain advantages over national authorities in stimulating integration and strengthening social cohesion: they are better at engaging with migrant organizations due to their closer proximity, and they are thought to be more capable of identifying the relevant integration priorities and devising tailored policies (Penninx 2009). Migrants, moreover, often feel more emotionally connected to the city than the country they live in. Whereas the city is associated with a diverse group of people, the country is more associated with one nationality (Bockhove 2012; Van der Welle 2011; Entzinger 2006). Local governments are also likely to be more open to migrant transnational affiliations compared to national governments (Bauböck 2003a, b in Østergaard-Nielsen 2011).

In the literature on city-to-city partnerships, several authors emphasize the power of these partnerships in terms of strengthening local governance processes, while two-way knowledge exchange also occurs (Johnson and Wilson 2009; Van Ewijk 2013).

There are two main types of linkages between cities, villages, or regions. The first is local governments - the administrative bodies, town halls, or policy departments-in origin and destination countries working together in city-to-city or townto-town partnerships. The bodies involved (e.g., social affairs, police, or fire department) typically work either with other local government bodies or in collaboration with nongovernmental organizations (NGOs) and the private sector. The second type of linkage is that in which a local government supports co-development ${ }^{2}$ initiatives of the nongovernmental actors in their jurisdiction without being actively involved in the transnational exchange (Van Ewijk 2013). The engagement

\footnotetext{
${ }^{2}$ We define co-development as the involvement of migrants and migrant organizations in development cooperation programmes linked to the migration and development policies of European donor countries.
} 
of immigrants in such cooperation projects is generally thought to enhance their integration in the destination country. The practices of municipalities differ widely between countries. For example, direct local government support is central in linkages based in the Netherlands, whereas support to NGO initiatives is central in those based in Spain (Acebillo-Baqué and Østergaard-Nielsen 2011; Van Ewijk 2013; Fauser 2007).

Local governments involved in transnational exchanges with countries of origin might focus on the countries where specific groups of migrants originate from or have an open policy towards all migrant groups. Most of the initiatives studied include the migrant groups that have been living in the countries of destination for a relatively long period of time, like labour migrants who migrated to Western Europe in the 1960s and 1970s (e.g., Moroccan and Turkish migrants in the Netherlands) or migrants originating from former colonies (e.g., people from Senegal, Mali, Burkina Faso, Ivory Coast, Morocco, and Tunisia migrating to France). Linkages with "new" emigrant countries, like Afghanistan and Sudan, are not mentioned in the literature. Ties between Eastern and Western European countries linked to the presence of migrants originating from Eastern Europe and residing in Western Europe, are similarly not discussed, and therefore fall outside the scope of this review.

\section{Motives and Frames of the Transnational/Translocal Activities of Local Governments}

Five factors explain why municipalities that host large migrant groups undertake transnational activities. First, stimulating integration and strengthening social cohesion in response to increased heterogeneity were important reasons for European municipalities to start cooperating with migrant origin countries (Schep et al. 1995; Shuman 1994; Van Ewijk 2013; Østergaard-Nielsen 2011). Bilgili and Agimi (2015) argue that integration has consistently been a goal for German municipalities to start cooperation with origin countries, although it is not always explicitly addressed. Strengthening community coherence has also been cited as a reason for local authorities to be involved in international exchange programmes (Green et al. 2005; Bilgili and Agimi 2015). Cities started transnational activities in the 1990s, a few decades after the first large-scale migration to Western Europe. Many initiatives were established between 2000 and 2008, against a background of economic growth coupled with increased societal tensions due to 9/11 (2001) and the terrorist attacks in Madrid (2004) and London (2005). Most partnerships were set up in destination countries, although some local governments in origin countries took the initiative to establish partnerships. A group of Moroccan municipalities, for instance, took the lead in seeking cooperation with Dutch local governments through the Association of Dutch Municipalities (Van Ewijk 2013). Most West European municipalities already had experience with international cooperation that they could build on, and linking with migrant source countries was a logical next step (Østergaard-Nielsen 
2011; Van Ewijk 2013). Budget cuts and fragile political and public support for international cooperation meant that some municipalities were seeking ways to benefit from international cooperation. Strengthening social cohesion was considered a way to do so. For these municipalities, the question was "why don't we link our international cooperation policies to integration policies so that we can gain something from the international exchanges" rather than "can international cooperation provide a new, creative way to stimulate integration". Local authorities in sending countries are often restricted by limited capacity and insufficient legal competence to be involved in international cooperation (Bilgili and Agimi 2015; Van Ewijk 2013).

Second, migrant groups often catalyse transnational activities. ${ }^{3}$ In municipalities that host large migrant populations, the translocal linkages already established at the civil society level may stimulate local governments to also get involved in international cooperation. In some cases, representatives of local governments with roots in origin countries (like Dutch or German city councillors and policy advisors of Moroccan and Turkish descent) have taken the lead in establishing local government initiatives (Bilgili and Agimi 2015; Van Ewijk 2013).

Third, national government policies or organizations operating at a regional or national level have played a stimulating role. According to Van Ewijk (2013), nationally funded support programmes have had a strong impact on the partnerships between Dutch municipalities and municipalities in Morocco and Turkey. Most of these programmes have focused on transferring knowledge from destination to origin countries, to strengthen local governance processes in the latter. ØstergaardNielsen (2011) observes that a development cooperation agency of the municipalities in Catalonia fulfilled an important role in stimulating transnational engagement.

Fourth, the mobility of people between origin and destination countries creates particular challenges, which have motivated local governments to start cooperating. To combat cross-border criminal activities and transnational terrorism, for example, international cooperation between actors operating at the local level may be required (Piperno and Stocchiero 2005). ${ }^{4}$

Finally, Grillo and Riccio (2004) point out that ambiguity might accompany codevelopment initiatives, as local-level actors, including local governments, may use linkages to stimulate remigration. Diatta and Mbow $(1999,254)$ observe that an AIDS project with Senegal was linked to an examination of the possibilities for the voluntary return of Senegalese migrants, while Schmidt di Friedberg (2000) notes that the anti-immigrant regional party in Italy (the Northern League) encouraged

\footnotetext{
${ }^{3}$ In the Dutch-Moroccan and Dutch-Turkish partnerships studied by Van Ewijk (2013), migrants also acted as translators and facilitators in the process of knowledge exchange and learning, and as resource persons for knowledge and networks.

${ }^{4}$ Terrorism and security are also directly linked to integration policies. Piperno and Stocchiero (2005) introduce the term "transnational integration", referring to the requirement for more effective integration policies at the local level, based on intercultural dialogue and the sharing of human and democratic rights and obligations. They argue that local governments can fulfil a specific role in promoting new forms of governance and partnerships with migrants, civil society organizations, and the private sector.
} 
NGOs to engage in development with the objective of halting immigration (Grillo and Riccio 2004). In 2011, the right-wing Belgian political party Vlaams Blok established contacts with Emirdağ (Turkey) and launched a campaign to stimulate the remigration of citizens of Turkish descent from Gent to Emirdağ called "Emirdağ Needs You". The campaign provoked strong negative reactions from people of Turkish descent living in Gent (Van Ewijk 2013).

It should be noted that economic motives have also played a role in initiating cooperation between migrant origin and destination countries. Local governments hope to stimulate transnational investments from companies. The literature, however, contains few examples where these motives were central.

\section{Impacts of Local Governments' Transnational Activities}

Before discussing the impacts of local governments' transnational activities, it is important to note that because these policies peaked between 2000 and 2008, most research focuses on this period. Furthermore, empirical evidence of impacts is scarce. A few studies indicate that the city-to-city linkages have indeed helped to strengthen social cohesion in destination countries, although they do not discuss impacts in detail. Examples include cooperation between two London boroughs and partners in Sierra Leone and Bangladesh, respectively (Evans 2009). Grillo and Riccio (2004) discuss the work of Cuffini and colleagues (1993), who argue that the city-to-city linkages between French and African countries (including several countries of origin) were relevant in combating racism in France. Similar impacts are reported for city-to-city linkages connecting the Netherlands with Morocco and Turkey (Van Ewijk 2013).

According to Van Ewijk (ibid.), Dutch actors have learned about issues related to integration through exchanges and, moreover, linkages between institutions and citizens of Moroccan and Turkish descent were to some extent also strengthened. The international programmes either functioned as "icebreakers" between formal institutions and migrant groups, or facilitated learning on sociocultural issues. For instance, teachers involved in an exchange programme with Turkey said they could now communicate more easily with the parents of Turkish children at their school. Police officers who had visited a Moroccan partner municipality reported that they could now better relate to migrant groups, as they had acquired an understanding of the challenges faced by migrants living in their municipality. The cooperation between the police department of Rotterdam and that of Casablanca is an example of transnational exchange on terrorism and transnational crime. This programme has enabled the Rotterdam police to build networks and knowledge about how the Moroccan police operate (e.g., its hierarchical organization), facilitating cooperation with Morocco in tracing people suspected of criminal activities (ibid.). Knowledge about impacts in origin countries is extremely limited. According to Van Ewijk (ibid.), several of the Dutch-Moroccan and Dutch-Turkish municipal partnerships she studied had a dual focus: to strengthen social cohesion in the 
Netherlands and to strengthen local governance processes in Morocco and Turkey (usually in terms of service delivery and citizen participation). The partnerships were particularly important in promoting multi-stakeholder collaboration, as the exchanges stimulated cooperation between governmental and nongovernmental actors in both Morocco and Turkey. In the cases studied, few linkages between governmental and nongovernmental actors had existed before the partnership was created. For instance, in a partnership between Haarlem (the Netherlands) and Emirdağ (Turkey), the University of Afyon worked together with a primary school, an environmental NGO, a provincial environmental organization, and the municipality to improve the waste management system and introduce a waste collection system. These arrangements should be viewed against the background of the decentralization processes that are taking place in many countries, including Turkey, whereby responsibilities and budgets are being transferred from the central to the local government level. Hence, local governments are increasingly seeking to work in multiactor arrangements (Pierre 2000; Van Kersbergen and Van Waarden 2001).

There are few examples of local governments in North-Western Europe supporting NGO co-development initiatives without being actively involved in the exchange. Nonetheless, the idea of co-development was well established by the late 1990s in France, where it received official acknowledgement and also influenced governments and policies elsewhere in Europe (Grillo and Riccio 2004). The approach was central in Catalonia where a large number of local governments were engaged in supporting the initiatives of community-based organizations and NGOs (ØstergaardNielsen 2011). This phenomenon was also observed in Italy, although few Italian local authorities actually engaged in co-development projects (Grillo and Riccio 2004). Research on the impacts of these activities is scarce. According to ØstergaardNielsen $(2011,36)$, it will only be possible to evaluate the dynamics of codevelopment policies once more programmes have run their course. Most studies refer to various initiatives or analyse the impacts of these programmes on the groups of migrants who undertake the activities. Although most co-development programmes are open to all migrant groups living in municipalities in destination countries, among initiatives in origin countries those of West African migrants are clearly dominant. The migrant collectives with the highest participation rates in Catalonia were comprised of migrants from Senegal, Equatorial Guinea, and Gambia, though the migrant populations originating from these countries represents only $3 \%$ of the total migrant population. The two largest groups in Catalonia (Moroccan and Ecuadorian migrants) were less involved, and representatives of these groups indicated that they were focusing more on integration processes within Catalonia (Østergaard-Nielsen 2011). The literature describes several other initiatives by West African migrants, including those of Malian migrants living in Saint Denis, a suburb of Paris (Petiteville 1995; Grillo and Riccio 2004). A limited number of initiatives by Italo-Senegalese organizations and Senegalese organizations linked to or supervised by Italian organizations are also mentioned (Grillo and Riccio 2004). Grillo and Riccio discuss the importance of transnational networks but also note problems of control and misunderstandings related mainly to naive expectations and the idealization of partners. Policies are sometimes also received with scepticism by migrants, 
as they feel they are 'token participants without any real influence' (ØstergaardNielsen 2011, 32). Grillo and Riccio (2004, 109) conclude that co-development is 'no better nor worse than more conventional forms of development'.

An interesting "three-way" integration process is that of some municipal partnerships, whereby countries of origin play a role in supporting the integration process in destination countries. Gilgili \& Agimi (2015) refer to examples of direct subnational support for emigrant employment, health care, and political participation. Van Ewijk (2013) reports, for instance, that administrative staff and policy advisors of municipalities in northern Morocco were willing to dedicate time and knowledge to strengthen the integration of Moroccan migrants in the Netherlands, as they felt the Moroccan migrants were trapped between two countries with different cultures. As the former mayor of $\mathrm{Al} \mathrm{Hoceima} \mathrm{(Morocco)} \mathrm{put} \mathrm{it,} \mathrm{'It} \mathrm{was} \mathrm{obvious} \mathrm{that} \mathrm{these}$ people did not have a good relationship with their father or their mother. It's not their fault; it is the parents' (cited in Van Ewijk 2013, 207). The limited engagement of parents of Moroccan descent with their children's Dutch schooling was one of the key issues discussed, and Moroccan officials were also involved in stimulating migrants to participate in elections. Community-based organizations that have been part of a city-to-city partnership have also been actively involved in exchanging knowledge on issues related to integration. An example is an exchange between women's organizations in Meppel (the Netherlands) and Al Hoceima, whereby women of Moroccan descent in Meppel were challenged by women in Al Hoceima to play a stronger role in their own municipality.

As discussed elsewhere in this chapter, few examples of these "three-way" integration process are described in the literature, and there is limited knowledge about the role of local authorities in sending countries. These activities are hampered by the limited capacity and mandates of local authorities in origin countries, and obviously they can only contribute to immigration integration in cooperation with local authorities in destination countries (Bilgili and Agimi 2015).

\section{Linking the Local Level "Here" and "There": Migrant Organizations}

There is an impressive number of migrant organizations in Europe (see Riccio 2008, 227; Cebolla Boado and López-Sala 2012; Van Heelsum and Voorthuysen 2002; Van Heelsum 2004). These organizations are highly diverse. Some have a religious function (e.g., the Ghanaian migrant churches in the UK and the Netherlands), while others focus on sports and leisure. Specific groups may also be targeted, such as youth, women, and particular ethnic groups. Moreover, migrant organizations perform multiple roles. They may facilitate the integration of their members in the destination country by providing information, for example, about housing, daycare, and health services, as well language and integration courses (they sometimes also deliver such courses). By connecting migrants with one another in destination countries, they help to build the migrant network. 
Another role played by many migrant organizations, and particularly hometown associations, is to link a region of origin with the destination country. It is this role that we examine in this section, addressing the main characteristics of the transnational activities of migrant organizations, discussing the background of these activities and the factors that explain the start of these activities, and analysing these activities. The transnational engagement of migrant organizations is a relatively new field of study that began in the USA with research on Latin American (Portes et al. 2007; Orozco and Garcia-Ganello 2009), Chinese (Portes and Zhou 2012), and Indian migrant collectives (Agarwala 2015). Until recently, few studies were available on the European context; but that body of literature is growing rapidly. ${ }^{5}$

\section{Characterizing the Transnational Activities of Migrant Organizations}

Most migrant organizations have some form of contact with the country of origin. The intensity of this contact varies from rather incidental to structural. As such, not all migrant organizations can be considered "transnational" or "translocal". The core business of the great majority is focused on the country of destination, to facilitate the integration of migrants in the host society. The relationship of migrant organizations with the country of origin can take many forms, and several categories of activities can be distinguished. For instance, organizations can play the role of broker or political activist, or be a charity or a professional development organization. These roles are not mutually exclusive.

Many migrant organizations perform the role of a broker between the migrant and the country of origin in the practical organization of essential lifecycle events, such as marriage, child birth, and funerals. Examples are migrant organizations that assist in repatriation of the deceased. Migrants often prefer to be buried in the country of origin, which is a costly and complex practice for families, as it requires extensive paperwork and knowledge of the system (Mazzucato and Kabki 2009). Lacroix (2010a) describes how in France the organizations of Algerian Kabyle fulfilled this role to build a bridge between the host society and the region of origin. Another example of an intermediary role played by migrant organizations is in payments of migrants' community taxes in the country of origin to compensate for not performing communal duties. Migrant organizations collect this money and forward it to the community in the region of origin.

Migrant organizations may embark on political activism, as a strategy to change political structures in the country of origin. This may range from advocacy work to

\footnotetext{
${ }^{5}$ See also Mazzucato and Kabki (2009) on Ghanaian migrant associations; Nijenhuis and Zoomers (2015) on Ghanaian, Surinamese, and Moroccan organizations in the Netherlands; Godin et al. (2012) on Congolese and Moroccan associations in Belgium; Lacroix and Dumont (2012) on Moroccan associations in France; Cebolla Boado and López Sala (2012) on various migrant associations in Spain; Van Naerssen et al. (2006) on African migrant organizations in the Netherlands; and Grillo and Riccio (2004) on Senegalese initiatives in Italy.
} 
electoral participation and features strong affiliation with particular political parties and a questioning of governance systems. Several political parties in origin countries have established branch organizations in countries of destination to reach out to the diasporas. Associations of migrants of Moroccan decent offer an example of strong political involvement, and several of these organizations have argued for political reform and democratization (Bakewell 2009). Related to political involvement is the claim for an improved rights position and the quest for improved conditions of return migration.

Migrant organizations may also be involved in charities, targeting their villages or region of origin. For some, the charity is their main activity and raising resources to support a specific project is their core business. They do so by organizing information meetings within their community, holding fairs to raise money, and approaching companies in their networks. These resources can be in-cash or in-kind. An example of the latter is computer equipment sent to schools in Surinam, or shipping the complete contents of a hospital to Ghana. Charities are often relatively shortterm, small-scale activities with a limited scope and are comparatively simple to implement. They aim to provide direct relief, for example, after an emergency and to satisfy certain needs. This kind of activity is very common among migrant organizations and has been a central practice from the time the first migrants set foot in Europe. Lacroix (2005) recalls, in this respect, the construction of a mosque in Morocco in the 1960s by migrants based in France.

A final category of activities can be classified as more professionally developed international development cooperation. These activities aim explicitly to stimulate development beyond the individual level in the country or village of origin. This category differs from the previous one in terms of the professionalization, budget, scale, and scope of activities. They are often implemented in the form of programmes and projects to stimulate development with a structural character. Resources to finance these activities may stem from state agencies and NGOs working in development cooperation. Sankofa is one such organization. It is based in the Netherlands and implements activities such as a family poultry project in Ghana.

The transnational activities of migrant organizations require the involvement of third parties. The local counterpart in the region of origin facilitates implementation of activities, keeps an eye on progress, and negotiates with stakeholders. The great majority of migrant organizations collaborate with a partner in the country or locality of origin, sometimes through a local NGO, sometimes through relatives, and sometimes through a counterpart organization established by the migrant organization especially for this purpose (Nijenhuis and Zoomers 2015; Godin et al. 2012; Lacroix and Dumont 2012). Besides these direct partners in the country of origin, migrant organizations collaborate with local and national governments there. Such collaboration is often mandatory to obtain permits for constructing schools and health posts, and is often considered "a necessary evil". However, positive collaborations with local governments are also mentioned, such as the partnership between Stichting Twiza Fonds (in the Netherlands) and the Moroccan municipality of Dar El Kebdani (Nijenhuis and Zoomers 2015) and, as mentioned earlier, various initiatives being implemented under the umbrella of municipal partnerships. 


\section{Motives and Frames of Translocal Activities of Migrant Organizations}

Although studies of the transnational activities of migrant organizations are advancing, few address the question of why migrant organizations, as collectives, become transnationally active (Morales and Jorba 2010; Lacroix 2010a). The motives that do emerge encompass four categories: moral, political, economic, and philanthropic. Moral bonds lie at the basis of many of the transnational activities of migrant organizations. These bonds are strongly associated with the relationship between migrants in the destination country and the non-migrants remaining in the village of origin. Migration impacts the identity of a community and changes the roles or the status of the individuals attached to that community. Migration both separates and binds people. Villagers may support each other by providing money, offering places to stay, and establishing care systems for those who remain. As such, migration shapes a "moral framework" (Lacroix 2010a, 10). The role of migrant collectives, hometown associations in particular, is to guarantee that migrants comply with all kinds of communal duties while they are abroad, as "long-distance villagers" (Lacroix 2010a, 10; Godin et al. 2012; Fox and Bada 2008). Moreover, migrants' participation in development projects gives them a certain legitimacy towards the non-migrants (Lacroix 2009; see also Henry and Mohan 2003, 615).

The quest by migrant organizations to engender political change in their country of origin can be a driver of transnational activities. In this respect, the question is to what extent the activities of migrant organizations can be considered political transnationalism. Some authors consider almost all activities to be political, as they change the local development scene and force local actors to react. Here, we use a narrower interpretation of the concept of political transnationalism as those activities that are directly related to political participation. Examples are efforts to extend political rights to migrant communities, to reincorporate returnees into homecountry politics, to empower local communities as a starting point for wider political change, and calls for democracy and political reform (Østergaard-Nielsen 2003; Itzigsohn 2000). Lacroix and Dumont (2012) mention in this respect the emergence of "a political voice" of Moroccan associations abroad. Moroccan migrant organizations have called attention to the contradiction between the impossibility of renouncing the Moroccan nationality and the lack of the right to vote and be represented in parliament. Economic motives of migrant organizations can be confined to the country of origin or extend to other developing countries. For instance, by pooling funds for investments in income-generating activities, migrant organizations may expect economic profit in the long run. Furthermore, by investing in the local economy, migrant collectives (e.g., hometown associations) might seek to improve the conditions for their own return (Schüttler 2008; Lacroix 2005; Henry and Mohan 2003).

Altruistic motives are another driver of the transnational activities of migrant organizations. Several studies point to the fact that migrant organizations, as collectives, want to do something for their communities back home. They feel privileged 
because of the opportunities offered to them in their new home country, such as access to education, good health services, and a relatively high standard of living, and they want to share some of this acquired wealth with their relatives in the country of origin. This is distinct from the moral motive, as it is less focused on maintaining specific relationships with the village of origin, as set in a moral framework with migrants still being considered part of the village of origin. Philanthropy is particularly mentioned among recently established migrant organizations and among organizations involved in charities (Lacroix 2010b; Nijenhuis and Zoomers 2015).

Over time, changes have occurred in the character of the transnational orientation of migrant organizations. The emergence of co-development schemes, and the funding opportunities derived from them, has influenced migrant organizations in two ways. First, it has led to a reorientation of the objectives of migrant organizations, resulting in an increase in the number of migrant organizations that focus on development activities within the realm of international development cooperation. Examples of countries where this is observed are France (Lacroix and Dumont 2012), Spain (Cebolla Boado and López-Sala 2012), and the Netherlands (Nijenhuis and Zoomers 2015).

Second, co-development schemes have resulted in the establishment of new migrant organizations that focus almost exclusively on development-oriented activities. Nijenhuis and Zoomers (ibid.) mention the establishment by Ghanaian migrants of several new migrants organizations in the Netherlands. The greater availability of funding has enabled these organizations to become professional development NGOs. A number of new Moroccan organizations have emerged since 2000. These organizations are dedicated solely to development activities in Morocco, and the availability of co-development funds (from the Dutch government) was an important incentive for their establishment (ibid.).

The policies of origin countries have also contributed to change the roles of migrant organizations. According to Godin and colleagues (2012), country-of-origin policies (Morocco in this case) play an important role in enabling associations of migrants (in Belgium) to gain funding. Although funds coming from the Moroccan government through the "Moroccan Citizens from Abroad" association were limited in absolute terms, they served to increase the political and symbolic legitimacy of these organizations and thus enhanced transnational development activities.

\section{Transnational Activities by Migrant Organizations: What Difference Do They Make?}

With the increasing prominence of the migration and development framework, assessments of the transnational activities of migrant organizations seem to be narrowing to a somewhat output-oriented and normative interpretation of "development", expressed in quantitative terms (e.g., the amount of money remitted, the number of schools built, or the number of laptops shipped). In this framework, migrant organizations are reduced to a tool for development-one that 
policymakers are increasingly encouraged to use. The overall picture, according to this view on development, is that the transnational activities of migrant organizations remain relatively small in scale and focused mainly on infrastructural projects in the social sectors (e.g., construction of a health post or school or the improvement of a village square) (Sinatti and Horst 2014; Portes et al. 2007; Nijenhuis and Zoomers 2015). Much of the academic literature takes a broader perspective, analysing the role of migrant organizations while also paying attention to other dimensions of development (e.g., political and social).

It is evident that the transnational activities of migrant organizations do affect the local context in the country of origin. They change this local context and also affect the relationship between the state and civil society. First, when implementing infrastructural projects, migrant organizations seek the consent of local authorities, which are not always willing or able to provide such support. Second, migrant organizations may initiate a discussion about the relationship between the state and civil society. Some organizations are rather critical about the role of the state, as shown by Fox and Bada (2008), who studied Mexican hometown associations in the USA. These associations blamed local governments in villages of origin for failing to provide necessary basic services to the local population. These migrant associations claimed a voice in municipal investments, as their collective investments had freed up part of the municipal budget, which could then be allocated to other investments.

Studies on the impact of the transnational activities of migrant organizations in destination countries are scarce. A few observations can be made, though, in particular on the relationship between transnational activities and integration. First, implementing transnational activities in the country of origin provides migrants who are not fully integrated in the host society a "refuge", that is, access to a social environment linked to their own culture and identity (Marini 2014). Second, through transnational activities, members of the organization get to know one another and exchange information and knowledge, which supports integration among those recently arrived. Third, the transnational activities of migrant organizations often depend on the support of other stakeholders, such as private organizations, public sector entities, and other migrant organizations. This collaboration could have leveraging effects, for example, increasing access to information and networks. This might foster social cohesion (JMDI 2010) and increase opportunities for collaboration in other policy fields (Marini 2014; Levitt and Lamba-Nieves 2011).

The direction in which migrants' collective transnational activities will develop further is rather uncertain. It is likely that not only the orientation of transnational activities of migrant organization will change, but so too will the intensity of these activities, due to the emergence of a second and even third generation and increased integration. Second and third generations might no longer be supportive of transnational initiatives in the country of origin, an issue mentioned by various authors (Nijenhuis and Zoomers 2015; Lacroix 2010a, b). Young people who were not born in their parents' country of origin may not share their parents' feelings of belonging to that specific locality. As a result, they might be disinclined to engage in transnational activities oriented towards their parents' birthplace. Another hypothesis is 
that they will retain a feeling of connection to their country of origin, but not to the specific locality their parents originated from. In that case, we could expect to see a decrease in specific translocal activities in favour of transnational activities in the country of origin, or in other developing countries. Moreover, younger generations may not feel connected to or represented by organizations established by their parents' generation (Open Society Foundations 2014). The extent to which migrants are embedded in the country of destination is important too. If migrants over the course of time integrate and spread geographically within the destination country, the rationale to be a member of a hometown association decreases, as Henry and Mohan (2003, 618) found in their study on Ghanaian migrant organizations in Milton Keynes (UK).

\section{Conclusion}

This chapter has examined translocal relationships at the meso level, in particular, those linking local governments and migrant organizations in the country of destination with those in the country of origin. Our review shows that both types of linkages produce a gamut of activities, from knowledge exchange through municipal partnerships to the subsidizing of migrant civic organizations, provision of charity goods, and lobbying for migrant rights.

A few observations can be made regarding the main characteristics of these activities. First, translocal activities by migrant organizations are sometimes funded by local governments, and municipal partnerships with countries of origin are sometimes mediated by migrant organizations. Second, translocal activities are usually initiated by local governments and migrant organizations in countries of destination. Third, translocal activities are generally not the core business of local governments and migrant organizations; their focus is typically on the migrant destination country.

This raises the question why actors at the meso level engage in translocal activities. Our analysis found that the desire to strengthen social cohesion and stimulate integration at the local level is usually the main driver for local governments. Local governments start partnerships with cities in countries of origin or support initiatives of migrant organizations in their own municipalities mainly because they expect to reap added value from connecting their integration policies to international cooperation. In addition, they are involved in processes aiming at strengthening local governance in partner municipalities. For migrant organizations, the picture is more diffuse, with a mixture of moral obligations, political and economic objectives, and philanthropy as central features.

Additionally, local government partnerships between migrant origin and destination countries suggest an equal relationship, having a two-way character, with potential benefits for both parties. Such an explicit two-way character is often absent from local governments' support to translocal activities by migrant organizations and initiatives of migrant organizations. 
From an economic perspective, the development impact of activities is relatively limited, as they are relatively small in scale and mainly related to social infrastructure, such as the construction of schools or the provision of hospital equipment (by migrant organizations), or waste management and public safety (by local governments). More important, however, is the impact these linkages have on other dimensions of development, like the relationship between the state and civil society. This applies to both municipal partnerships and the initiatives of migrant organizations. Examples include the effect of municipal partnerships in improving the interface between local government and civil society actors in countries of origin and the results of lobbying by a migrant organization for an improved position of women in the country of origin. Moreover, our review of the literature suggests a positive relationship between translocal activities at the meso level and integration in the country of destination.

Although the literature is sparse on strengthening social cohesion through local governments' international activities, the available findings confirm previous research suggesting that engagement in international exchange programmes enhances integration in the destination country. Similar effects can be observed for the activities of migrant organizations, as translocal activities force them to become active members of society in the country of destination. However, the relationship between integration and transnational activities depends on the characteristics of diasporas and policies and funding opportunities in the country of destination. Moreover, the added value of these policies should not be overstated. Most synergy between translocal activities and integration is created by activities that actively link translocal efforts to the country of destination, for example, in multi-actor collaborations, such as those encompassing migrant organizations, NGOs, and other civic and public sector organizations (see also Marini 2014).

Adding to this, an interesting form of "three-way" integration is reported whereby actors at the meso level in a country of origin play a role in supporting integration processes in the country of destination. Moroccan municipalities, for instance, dedicated their time and knowledge to stimulate the participation-political and otherwise — of Moroccan migrants in Dutch municipalities.

Our review found that policies and funding opportunities are crucial elements. Various national and local governments have implemented co-development policies (accompanied by funding schemes) to support initiatives by migrant organizations within the framework of migration and development. This has shifted the orientation of local governments and migrant organizations towards a more developmentoriented approach and triggered the emergence of new migrant organizations. The emphasis on translocal activities from a migration and development perspective has implications for the interpretation of these activities. To start with, policymakers have tended to consider migrants and their organizations mainly as a "development tool", ignoring other, perhaps more important, roles. Moreover, from this perspective, development is often narrowed down to a rather output-oriented and normative view focused on, for example, the size of collective investments or the number of schools built, rather than on processes of social transformation (see also Sinatti and Horst 2014). Finally, one might question the motives underlying this framework. 
Some municipalities, for instance, have had controversial objectives like encouraging remigration. Questions could also be asked about the way initiatives are set up, executed, and assessed.

The economic crisis and resulting budget cuts in Western Europe since 2008 has put co-development programmes under pressure, threatening along with them some migrant organizations' funding for translocal activities. Funding constraints have also affected the activities of local governments in origin countries, as all levels of government have had to slash budgets. Nationally funded support programmes have been phased out, which has had an impact at the local level (Van Ewijk 2013). According to Van Ewijk (ibid.), linking to countries of origin remains on the agendas of those local governments that have already established linkages, but financial resources dedicated to these partnerships have been reduced, and government actors are playing a less intensive role, creating more room for civil society to step in. Some local governments have shifted their international cooperation focus to economic objectives and increasingly focus on partnerships with cities in emerging economies like the BRICS (Brazil, Russia, India, China, and South Africa). As such, the transnational linkages of local governments and migrant organizations represent a highly dynamic form of relationship between countries of destination and countries of origin.

Open Access This chapter is distributed under the terms of the Creative Commons AttributionNoncommercial 2.5 License (http://creativecommons.org/licenses/by-nc/2.5/) which permits any noncommercial use, distribution, and reproduction in any medium, provided the original author(s) and source are credited.

The images or other third party material in this chapter are included in the work's Creative Commons license, unless indicated otherwise in the credit line; if such material is not included in the work's Creative Commons license and the respective action is not permitted by statutory regulation, users will need to obtain permission from the license holder to duplicate, adapt or reproduce the material.

\section{References}

Acebillo-Baqué, M., \& Østergaard-Nielsen, E. (2011). Local dynamics of co-development and migrant incorporation in three Catalan cities. Paper presented at the international RC 21 conference 2011, The struggle to belong: Dealing with diversity in the 21 st century in urban settings. Amsterdam, 7-9 July.

Agarwala, R. (2015). Tapping the Indian diaspora for Indian development. In A. Portes \& P. Fernandez-Kelly (Eds.), The state and the grassroots: Immigrant transnational organizations in four continents. New York: Berghahn Books.

Bakewell, O. (2009). Which diaspora for whose development? Some critical questions about the roles of African diaspora organisations as development actors. DIIS brief. Copenhagen: Danish Institute for International Studies.

Bauböck, R. (2003a). Reinventing urban citizenship. Citizenship Studies, 7(2), 139-160.

Bauböck, R. (2003b). Towards a political theory of migrant transnationalism. International Migration Review, 37(3), 700-723. 
Bilgili, O., \& Agimi, I. (2015). Supporting immigrant integration in Europe: What role for origin countries' subnational authorities? Brussels: Migration Policy Institute.

Bockhove, M. E. (2012). Geographies of belonging: The transnational and local involvement of economically successful migrants, Ph.D. dissertation, Erasmus University Rotterdam.

Cebolla Boado, H., \& López-Sala, A. (2012). A top-down model of transnational immigrant associations. Paper prepared for the transnational immigrant organisations seminar, Princeton, 11-12 May.

Cuffini, E., Diarra, M., \& Kébé, S. (1993). A propos des jumelages. Hommes et Migrations, 1165, $25-27$.

Diatta, M. A., \& Mbow, N. (1999). Releasing the development potential of return migration: The case of Senegal. Migration and Development, 37()1), 243-266.

Entzinger, H. (2006). Changing the rules while the game is on: From multiculturalism to assimilation in the Netherlands. In Y. M. Bodemann \& G. Yurdakul (Eds.), Migration, citizenship and ethnos: Incorporation regimes in Germany, Western Europe and North America (pp. 121-144). New York City: Palgrave Macmillan.

Evans, E. (2009). A framework for development? The growing role of UK local government in international development. Habitat International, 33(2), 141-148.

Fauser, M. (2007). Selective Europeanization: Europe's impact on Spanish migration policy. In T. Faist \& A. Ette (Eds.), Between autonomy and the European Union: The Europeanization of national immigration policies and politics (pp. 136-156). Houndmills: Palgrave Macmillan.

Fox, J., \& Bada, X. (2008). Migrant organization and hometown impacts in rural Mexico. Journal of Agrarian Change, 8(2-3), 435-461.

Godin, M., Rea, A., \& Thys, H. (2012). Comparison between 'networks of development' in Moroccan migrant organizations and Congolese migrant organizations in Belgium. Paper prepared for the second transnational immigrant organizations seminar, Princeton, 11-12 May.

Green, L., Game, C., \& Delay, S. (2005). Why should my local authority be involved in an overseas project? Understanding the domestic impacts of local government involvement in international development. Birmingham: School of Public Policy, University of Birmingham.

Grillo, R., \& Riccio, B. (2004). Translocal development: Italy-Senegal. Population, Space and Place, 10, 99-111.

Henry, L., \& Mohan, G. (2003). Making homes: The Ghanaian diaspora, institutions and development. Journal of International Development, 15(5), 611-622.

Itzigsohn, J. (2000). Immigration and the boundaries of citizenship: The institutions of immigrants' political transnationalism. International Migration Review, 34(4), 1126-1154.

JMDI. (2010). From migration to development: Lessons drawn from the experiences of local authorities. Brussels: Joint Migration and Development Initiative. www.migration4development.org/sites/m4d.emakina-eu.net/files/JMDI_Migration_to_Development_LA_report_ July2010.pdf

Johnson, H., \& Wilson, G. (2009). Learning and mutuality in municipal partnerships and beyond: A focus on Northern partners. Habitat International, 33(2), 210-217.

Juzwiak, T., McGregor, E., \& Siegel, M. (2014). Migrant and refugee integration in global cities: The role of cities and businesses. Working paper of the UNU Maastricht economic and social research institute on innovation and technology (UNU-MERIT), Maastricht graduate school of governance (MGSoG). The Hague: The Hague Process on Refugees and Migration (THP).

Lacroix, T. (2005). Les réseaux marocains du développement: Géographie du transnational et politique du territorial. Paris: Presses de Sciences Po.

Lacroix, T. (2009). Transnationalism and development: The example of Moroccan migrant networks. Journal of Ethnic and Migration Studies, 35(10), 1665-1678.

Lacroix, T. (2010a). Bonding collective? The moral infrastructures of transnational hometown networks. IMI working papers 27. Oxford: International Migration Institute.

Lacroix, T. (2010b). Hometown organisations and development practices. IMI working papers 28. Oxford: International Migration Institute. 
Lacroix, T., \& Dumont, A. (2012). Moroccans in France: Their organisations and their activities back home. Paper prepared for the second transnational immigrant organizations seminar, Princeton, 11-12 May.

Levitt, P., \& Lamba-Nieves, D. (2011). Social remittances revisited. Journal of Ethnic and Migration Studies, 37, 1-22.

Marini, F. (2014). Transnationalism and integration: What kind of relationship? Empirical evidence from the analysis of co-development's dynamics. Migration and Development. doi:10.1 080/21632324.2014.919715.

Mazzucato, V., \& Kabki, M. (2009). Small is beautiful: The micro-politics of transnational relationships between Ghanaian hometown associations and communities back home. Global Networks, 9(2), 227-251.MPI (2008). Hometown associations: An untapped resource for immigrant integration?, Washington, DC: Migration Policy Institute.

Morales, L., \& Jorba, L. (2010). Transnational links and practices of migrants' organisations in Spain. In R. Baubock \& T. Faist (Eds.), Diaspora and transnationalism: Concepts, theories and methods. Amsterdam: IMISCOE Research. Amsterdam University Press.

Nell, L. (2007). Locally specific transnational ties: Turkish and Turkish-Kurdish immigrants in the Netherlands. In S. de Tapia, A. Guillouv, \& M. Wadbled (Eds.), Migrations turques dans un monde globalisé: Le poids du local (pp. 199-216). Rennes: Rennes University Press.

Nijenhuis, G., \& Zoomers, A. (2015). Transnational activities of immigrant organizations in the Netherlands: Do Ghanaian, Moroccan and Surinamese diaspora enhance development? In A. Portes \& P. Fernandez-Kelly (Eds.), The state and the grassroots: Immigrant transnational organizations in four continents. New York: Berghahn Books.

Orozco, M., \& Garcia-Ganello, E. (2009). Hometown associations: Transnationalism, philanthropy and development. Brown Journal of World Affairs, 15(2), 1-17. www.centralamerica. thedialogue.org/PublicationFiles/Hometown\%20Associations, \%20Transnationalism, \%20 Philanthropy,\%20and\%20Development.pdf

OSF. (2014). Somalis in Amsterdam. London: Open Society Foundations.

Østergaard-Nielsen, E. (2003). The politics of migrants' transnational political practices. International Migration Review, 37(3), 760-786.

Østergaard-Nielsen, E. (2011). Codevelopment and citizenship: The nexus between policies on local migrant incorporation and migrant transnational practices in Spain. Ethnic and Racial Studies, 34(1), 20-39.

Penninx, R. (2005). Dutch integration policies after the Van Gogh murder. Ottawa: House of the Commons.

Penninx, R. (2009). Decentralising integration policies: Managing migration in cities, regions and localities. Policy network paper. London: Policy Network. www.policy-network.net/uploadedFiles/Publications/Publications/Decentralising\%20integration\%20policies\%20FINAL $\% 20$ (Rinus\%20Penninx).pdf

Petiteville, F. (1995). La coopération décentralisée: Les collectivités locales dans la coopération Nord-Sud. Paris: L'Harmattan.

Pierre, J. (2000). Debating governance. Oxford: Oxford University Press.

Piperno, F., \& Stocchiero, A. (2005). Migrants and local authorities for the Euro-Mediterranean transnational integration. Rome: CeSPI Centro Studidi Politica Internazionale.

Portes, A., \& Zhou, M. (2012). Transnationalism and development: Mexican and Chinese immigrant organizations in the United States. Population and Development Review, 38(2), 191-220.

Portes, A., Escobar, C., \& Walton Radford, A. (2007). Immigrant transnational organizations and development: A comparative study. International Migration Review, 41(1), 242-281.

Pries, L. (2001). New transnational social spaces, international migration and transnational companies in the early twenty-first century. London: Routledge.

Riccio, B. (2008). West African transnationalisms compared: Ghanaians and Senegalese in Italy. Journal of Ethnic and Migration Studies, 34(2), 217-234. 
Robertson, R. (1994). Globalisation or glocalisation? Journal of International Communication, 1(1), 33-52.

Schep, G. J., Angenent, F., Wismans, J., \& Hillenius, M. (1995). Local challenges to global change: A global perspective on municipal international cooperation. The Hague: SDU.

Schmidt di Friedberg, O. (2000). Immigration et coopération en Italie. Migrations Société, 12(67), 256-258.

Schüttler, K. (2008). The contribution of migrant organisations to income-generating activities in their countries of origin. Working paper 50. Geneva: International Labour Organization.

Shuman, S. (1994). Towards a global village: International community development initiatives. London: Pluto Press.

Sinatti, G., \& Horst, C. (2014). Migrants as agents of development: Diaspora engagement discourse and practice in Europe. Ethnicities. doi:10.1177/1468796814530120.

Smith, J. (n.d.). Decentralised development cooperation: European perspectives. Brussels: Platforma. www.euroafricanpartnership.org/it/media/allegati/documenti/PLATFORMA\%20 decentralised_development_cooperation_-_european_perspectives.pdf. HYPERLINK http:// www.platforma-dev.eu/files/upload/608/decentralised-development-cooperation-europeanperspectives.pdf

Van der Welle, I. (2011). Flexibele burgers? Amsterdamse jongvolwassenen over lokale en nationale identiteiten. Ph.D. dissertation, University of Amsterdam.

Van Ewijk, E. (2013). Between local governments and communities: Knowledge exchange and mutual learning in Dutch-Moroccan and Dutch-Turkish municipal partnerships. Ph.D. dissertation, University of Amsterdam.

Van Heelsum, A. (2004). Migrantenorganisaties in Nederland. Utrecht: FORUM.

Van Heelsum, A., \& Voorthuysen, E. (2002). Surinaamse organisaties in Nederland: Een netwerkanalyse. Amsterdam: Aksant.

Van Kersbergen, K., \& Van Waarden, F. (2001). Shifts in governance: Problems of legitimacy and accountability. The Hague: Social Science Research Council (MAGW), NWO.

Van Naerssen, T., Kusters, J., \& Schapendonk, J. (2006). Afrikaanse migrantenorganisaties in Nederland: Ontwikkelingsactiviteiten en opinies over ontwikkelingssamenwerking. Nijmegen: Migration and Development Research Group.

Zoomers, A., \& Van Westen, G. (2011). Translocal development, development corridors and development chains. International Development Planning Review, 33(4), 377-388. 